ВИЩА ШКОЛА

\author{
UDC 811.111:378.4 \\ DOI https://doi.org/10.32840/1992-5786.2021.75-3.8
}

T. V. Lazarenko

Senior Lecturer at the Department of Pedagogies, Foreign Philology and Translation Simon Kuznets Kharkiv National University of Economics

\title{
TEACHING ACADEMIC WRITING TO STUDENTS OF NON-LANGUAGE INSTITUTIONS OF HIGHER EDUCATION AS AN INDEPENDENT TYPE OF LANGUAGE ACTIVITY
}

The study of a foreign language in institutions of higher education is an integral part of a comprehensive training program for modern specialists. Fluency in a foreign language means perfect mastery of the four common types of speech activity: listening, speaking, reading and writing. The article highlights the problems of teaching written language to students of non-language institutions of higher education in the process of learning a foreign language. The relevance of the article is due to the growing role of written language in the processes of communication and information exchange, which constitute a person's communicative system and are the individual needs of every person. Therefore, the formation of a culture of writing is one of the main tasks that contribute to the activation of general and communicative competencies in various situations that arise in different spheres of social life. The article distinguishes between the concepts of writing and written language, defines these concepts, and identifies the role and place of written language in the structure of foreign language teaching in non-language educational institutions. The role of writing and written language at different stages of learning a foreign language is determined. Such types of writing as writing for training, writing for communication, reasoned writing are considered. Writing for communication is developed through writing for training, which, in turn, is based on the technique of writing and on the developed graphic and spelling skills. The main purpose of teaching writing for communication is to develop the ability to create different types of written statements for educational, professional and social activities. The article substantiates the need to teach critical thinking to develop the skills of reasoned writing. The definition of the concept of reasoned writing is given. Attention is drawn to the use of secondary texts in the teaching of writing in a foreign language. The definition of the concept of the secondary text is given and it is offered to consider the translation into the native language that is used in training as the secondary text. It is argued that translation from a foreign language into a native language and from a native language into a foreign language is an effective means of establishing cross-language correspondences, which clearly demonstrates differences in the ways of seeing and describing reality in different languages. The article identifies prospects for further research in the field of teaching higher education students writing in a foreign language.

Key words: foreign language, writing, academic writing, reasoned writing, critical thinking, secondary text, training translation, communicative competence.

Formulation of the problem. Writing is one of the four types of language activity that forms a person's communicative system and ensures his or her social and cultural existence. Writing is considered the most difficult type of language activity for both native speakers and those who study it, because the author of a written text has to deal with such components of writing as content, organization of the text, purpose of writing, recipient or audience, vocabulary, grammar, spelling, punctuation. Learners need to set an objective for their writing, plan it carefully, think over its layout and logical structure, and revise it. In the process of writing they have to use cognitive skills; they have to analyze their sources and then synthesize them in a compact piece of writing. Therefore, knowing how to write in a foreign language is a valuable asset in foreign language communication. As K. Walsh puts it "Writing is important because it's used extensively in higher education and in the workplace. If students don't know how to express themselves in writing, they won't be able to communicate well with professors, employers, peers, or just about anyone else. Much of professional communication is done in writing: proposals, memos, reports, applications, preliminary interviews, e-mails, and more are part of the daily life of a college student or successful graduate". [1, p. 1] Writing is considered particularly difficult for foreign language students, as they are believed to have to create a finished product by mastering all the above elements of the new language.

Proficiency in written form of a language allows a person to really use the knowledge of a foreign language, being outside the language environment, and communicating with native speakers through modern means of communication: internet, e-mail, 
texting, etc. The ability to write personal and official letters, the need to fill out questionnaires and forms of documents motivate students to actively master written communication in the language they study. That is why the task of teaching writing in a nonlanguage institution of higher education is to teach students to write various texts on relevant topics, arguing their point of view in a foreign language.

The purpose of this article is to determine the place and role of written speech in the system of foreign language teaching and to substantiate its significance in the educational process.

The overview of recent studies and publications. Writing and written language were previously considered in the methodology of teaching foreign languages as a means of learning. In psychological and psycholinguistic aspects, the problem of teaching written language has been considered by many well-known scholars. Among them V. Artemov, L. Vygotsky, N. Zhinkin, I. Zimniaya, A. Leontyev, A. Luriya, and others. Over the past two decades, domestic language education has been replenished with a sufficient number of works devoted to teaching students reasoned written language in a foreign language (M. Altukhova, I. Antonova, E. Baranova, A. Gavrilova, A. Gorbunov, N. Guzhova, S. Musulbes, etc.).

However, the place of foreign written language in the educational process is not particularly significant, and textbooks do not provide for its gradual development. Therefore, improving the methodology of teaching written language in higher education is a matter of time.

The outline of main material. The modern foreign language training program determines the place and role of writing in the structure of foreign language teaching and includes it in the main goals of written language teaching. The role of writing and written language varies at different stages of learning. At the first stage, the aim of mastering the technique of writing is realized. At the second stage, the main thing is to learn spelling, which is due to the accumulation of new language material. At the same time, written language is being developed as a way to promote the formation of oral skills and abilities. At the senior stage, previously acquired written skills are improved along with the improvement of oral skills. Work on the spelling of new language material is also under way.

In the linguistic literature, a distinction is made between writing and written language. Writing is understood as a graphic system, as one of the forms of expression, a means that allows to represent the language with the help of signs and to fix its works for preservation in time and for transmission at a distance. In this case, written messages are considered as a product of language activities in writing. They are the object of learning to practice writing. Writing is composing words from letters, and written language is composing written messages from words and phrases. Thus, the basis of writing is the mastery of graphics and spelling. Written language is based on the ability to express thoughts using a graphic code. Writing should be considered both as a means of learning a foreign language and as a goal. When learning vocabulary, grammar, phonetics, it is impossible to do without writing words, structures, rules, etc. When developing listening skills, writing is used to record key information, prepare for the perception of new information. Written independent and control works are widely used while mastering vocabulary and grammar. Writing is also used as a means of control. It allows the teacher to check knowledge of vocabulary and grammar; to check how well the lexical and grammatical skills have been formed. [2, p. 2]

When we speak about writing as an independent activity, we mean written language. In the methodology of teaching a foreign language there exist such concepts as "writing for training" and "writing for communication". By writing for training we mean the performance of language and speech training exercises in writing $[3, p .110]$. These types of exercises are aimed at mastering lexical and grammatical skills and language skills. Writing for training promotes the formation of spelling and punctuation skills, improves knowledge of grammar and colloquial formulas, expands the active vocabulary and is the basis of communicative written language.

Writing for communication is "an expressive type of language activity aimed at generating a language message in writing" $[3, p .111]$. The development of writing for communication takes place with the help of writing for training, which is based on the technique of writing, as well as on the formed graphic and spelling skills. The main purpose of teaching this type of writing is to improve the skills to create different types of written communications for educational, professional and social activities.

T. Hedge identifies the following main types of expressive written language, depending on its purpose and scope of operation:

- academic writing - written language that is used for academic purposes, such as recordings and notes, surveys and reviews, essays, etc.;

- professional/business writing - written language used for professional purposes, such as business letters, advertisements/public notices, business notes (memos), articles, etc.;

- social writing - written language used to support the communication of social significance, such as personal notes, private letters, e-mails, etc.;

- personal writing - written language used to support communication for personal purposes, such as addresses, recipes, etc .;

- creative writing - written language that is used for expressive written communication and expression of feelings and emotions of the author, such as poems, stories, etc. [4, p. 112-113]. 
The purpose of teaching writing in this case is to teach students to write the same texts that any educated person can write in his/her native language.

These can be: filling out questionnaires; writing various letters and answers to them, including both official and personal; writing of resumes, autobiographies; writing various applications (for employment, for enrolment in studies); writing reviews, summaries and abstracts; writing reports, papers, essays, greeting cards, notes and lecture recordings, etc. In such texts special attention is paid to the content and structural organization. Obviously, learning to write some of these types of texts, such as different types of letters, notes, descriptions making use of concrete examples, begins at an early stage and goes towards broadening of the range of topics, increasing the volume, development of the necessary skills by the end of training, including training in institutions of higher education.

Actual skills of writing some other types of texts, such as papers/essays, reports, abstract, annotations, thesis, are taught only at the advanced level of training because of their greater complexity and specificity. Training them may become the goal of learning not before the students accumulate sufficient language experience; form the linguistic component of communicative competence. Only then the work should be aimed at further development of pragmatic and sociolinguistic components.

It is recommended to work on these types of texts at the stage of subject-oriented training within the planned specialty and in the context of future professional activity, thus contributing to the development of foreign language professionally oriented communicative competence.

Therefore, written language is not just a language transformed into graphic symbols, but also an independent process with its own grammar rules and construction of written text, the result of which interest the speaker. Within the communicative approach written language is perceived as a social action.

Training in the writing of these and some other types of documents is included in the training program for students of the specialty «International Business» of Kharkov University of Economics. Students learn to write various kinds of letters (applying for a job, offering a service, confirming an agreement, complaining about poor service or product, giving advice, suggesting a solution, expressing an opinion), reports (external - for clients, partners, suppliers; internal - for senior managers and for colleagues), essays (about pros and cons of a job, opinion essays), reviews and descriptions (about an event, about a visit, a description of a place or a building).

While teaching the students to write these documents we follow the product approach to writing. This approach usually involves the presentation of a model text, which is discussed and analyzed.
According to this model text learners construct a similar or a parallel text. This might seem a mechanical task; however, learners can discover the structure of the given discourse, its linguistic features and how its ideas are organized. [5]

First of all, students get acquainted with the purpose of the document. They then examine its structure by comparing it to a sample document. After that, they get acquainted with a list of useful expressions that are most often used in documents of this type, as well as a list of linking words that help structure thoughts (first, second, furthermore, in addition), emphasize contrast (on the other hand, however), to lead to findings and conclusion (to sum up, in conclusion). After that students perform tasks, the purpose of which is to prepare them to write their own document on a topic set by the teacher. Such tasks can be: underline the correct linking word/phrase; expand the notes into full paragraphs; match the given arguments to the reasons; match the given problems to the suggestions; fill in the given linking words; replace the informal expressions in the text/table with the formal ones, etc. The skills acquired in this way are then used to write their own text on a given topic.

The ability to write business documents is inseparable from the ability to present one's thoughts clearly, concisely and in reasond manner. That is why we consider it necessary to pay more attention to teaching reasoned writing.

Reasoned writing is a written judgment, which is a type of creative work that promotes the improvement of students' logical and critical thinking, the ability to prove truthfulness and accuracy of their own judgment or to refute the opponent's point of view. In this judgment, the writer sets himself the task of influencing the reader, convincingly proving his/her point of view. When teaching writing to students in foreign language lessons, the teacher forms their critical thinking. In this case, teaching writing is seen as a mental process that includes elements of critical thinking.

Bringing critical thinking into the process of teaching a foreign language helps students to improve their mental ability, expand communication skills, develop written competence and increase motivation.

The use of critical thinking skills in written language means studying different points of view, assessing one's own position and ability to present one's conclusions in a clear and reasoned form, the ability to convince other readers.

Critical writing does not mean disclosing the topic in a negative way. The author should be familiar with issues related to the topic of the essay, confident that he/she uses all sides of reasoning, should be able to see different approaches to the same problem. [6, p. 43].

Reasoned written expression is a product of mental activity, which is a complete text that includes conceptual and emotional elements and built according to the norms of written language and the 
laws of logic, which treats a problem from different positions to convince the opponent of the correctness of the author's thoughts. Reasoned writing is not taught at the primary level of learning, at the secondary level it plays just a minor role and acts more as a means rather than as a goal of learning. And only at the senior level of training reasoned writing becomes one of the leading activities. [7, p. 42-45]

Today, it is secondary texts that attract special interest in foreign language teaching methods. They are texts that are created on the basis of some other primary or original text. It is considered that to some extent this interest was provoked by linguistics, which in recent decades has been actively engaged in the study of secondary texts and has already identified some structural peculiarities of such texts and their functioning. [8, p. 37] It should be noted here that the translation into the native language used in teaching, no matter how it was treated in different periods of development of the methodology, can also be considered as a secondary text.

It is no coincidence that we mention here the written educational translation, to which many specialists on the methodology of teaching and practicing teachers have a negative attitude. Of course, one should listen and read a lot in a foreign language. This accelerates the transition to the direct perception of the content of what is read or heard without any mediation of the native language. Listening, writing and reading should develop interrelated as the mechanism of recoding develops. And so does the translation from the native and into the native language, if we consider it as an additional type of speech activity. Translation is a means of establishing crosslanguage correspondences, which optimizes the formation of the recoding skill. Moreover, translation into the native language is a powerful means of demonstrating differences in the ways of seeing and describing reality in different languages.

Thus, in conclusion, we can say that the role and place of writing and written language in foreign language teaching are determined by specific targets of learning. Learning to write involves mastering graphics, spelling, word formation, punctuation, a set of language intentions to express ideas in a coherent form. Therefore, teaching foreign writing should be comprehensive, taking into account the spelling, lexical, grammatical and stylistic norms of a foreign language; developing general and communicative (linguistic, socio-cultural, pragmatic) competencies.

Learning writing is realized in the process of mastering a set of relevant knowledge, language and communication skills that are necessary to create a written text that serves as a means of communication, both in the professional sphere and in everyday life.

The main purpose of teaching foreign productive writing is to form linguistic, communicative and social competence. Linguistic competence includes knowledge of the language and the rules of its functioning in the process of communication. Communicative competence in the field of foreign written communication involves the ability to perceive and generate foreign written statements in accordance with the conditions of communication. The formation of this competence aims to develop the ability to create such types of written statements (texts) that may be needed by a person in professional activities, as well as for personal purposes. Linguistic and social competence includes knowledge of the main features of socio-cultural development of the target-language country, and the ability to communicate in writing. Knowledge of a foreign written language is one of the means to increase the competitiveness of a specialist in the labor market. That is why an important task is to enhance the communicative function of writing as a type of language activity and to ensure that the objectives of teaching writing comply with modern requirements.

We believe that it would be appropriate to focus further research in this area on the development of such methods of teaching foreign writing that would contribute to the development of writing as an independent type of language activity and would be sufficient for the development of its complex levels.

\section{References:}

1. Walsh, K. (2010). The importance of writing skills: Online tools to encourage success. URL: http:// www.emergingedtech.com/2010/11/the-importance-of-writing-skills-online-tools-to-encourage-success/.

2. Колоницкая О.Л., Хруненкова М.Л. Обучение студентов иноязычной письменной речи. Эйдоc. 2010. URL: http://www.eidos.ru/ journal/2010/0319-8.htm.

3. Колесникова И.Л., Долгина О.А. Англо-русский терминологический справочник по методике преподавания иностранных языков. СанктПетербург : БЛИЦ, 2001. 224 с.

4. Hedge T. Writing. Resource Books for Teachers. URL: https://global.oup.com/academic/product/ writing-9780194421904?lang=en\&cc=it.

5. Steele, V. Product and process writing: a comparison. URL: http://www.teachingenglish.org.uk/think/ articles/product-process- writing- a- comparison.

6. Плотникова Н.Ф. Роль критического мышления при обучении студентов письму. Казанский вестник молодых ученых. 2018. Т. 2. № 5(8). C. $40-45$.

7. Лазаренко Т.В. Навчання аргументованого писемного мовлення студентів немовних спеціальностей закладів вищої освіти. Інноваційна педагогіка. 2019. Вип. 9. Т. 2. С. 42-45.

8. Агранович Н.Б. Вторичные тексты в коммуникативно-когнитивном аспекте : дис. ... канд. филол. наук : 10.02.19. Москва, 2006152 с. РГБ ОД, 61:06-10/849. 
Лазаренко Т. В. Навчання академічного письма студентів немовних закладів вищої освіти
як самостійного виду мовної діяльності
Вивчення іноземної мови в закладах вищої освіти є невід'ємною частиною комплексної програми Вивчення іноземної мови в закладах вищої освіти є невід'ємною частиною комплексної програми
оготовки сучасного спеціаліста. Вільне володіння іноземною мовою означає досконале засвоєння загальноприйнятих чотирьох видів мовленнєвої діяльності: слухання, говоріння, читання і письма. У статті висвітлюються проблеми навчання писемної мови студентів немовних закладів вищої освіти у процесі вивчення іноземної мови. Актуальність статті зумовлюється зростанням ролі писемного мовлення у процесах спілкування та обміну інформацією, які становлять комунікативну систему людини й є індивідуальними потребами особистості. Тому формування культури писемного мовлення є одним з основних завдань, які сприяють активізації загальної і комунікативної компетентностей у різноманітних ситуаціях, що виникають у різних сфрерах соціального життя. У статті розмежовуються поняття письма і писемної мови, дається визначення цих понять, визначаються роль і місце писемної мови у структурі навчання іноземної мови у немовних навчальних закладах. Визначається роль письма і писемної мови на різних етапах навчання іноземної мови. Розглядаються такі види писемного мовлення, як навчальне писемне мовлення, комунікативне писемне мовлення, аргументоване писемне мовлення. Комунікативне писемне мовлення розвивається через навчальне писемне мовлення, яке, своєю чергою, спирається на техніку письма і на сфрормовані графрічні й орфрографрічні навички. Основною метою навчання комунікативного писемного мовлення $є$ розвиток умінь створювати різні види письмових повідомлень для навчальної, профресійної і соціальної діяльності. У статті обгрунтовується необхідність навчання критичного мислення для розвитку навичок аргументованого писемного мовлення. Дається визначення поняття аргументованого писемного мовлення. Привертається увага до використання вторинних текстів у навчанні писемного мовлення іноземною мовою. Дається визначення поняття вторинного тексту і пропонується розглядати використовуваний у навчанні переклад на рідну мову як вторинний текст. Стверджується, що переклад з іноземної мови на рідну і з рідної на іноземну є дієвим засобом установлення міжмовних відповідностей, який наочно демонструє розбіжності у способах бачення й опису дійсності в різних мовах. Стаття визначає перспективи подальших досліджень у галузі навчання студентів закладів вищої освіти писемного мовлення іноземною мовою.

Ключові слова: іноземна мова, письмо, писемне мовлення, аргументоване писемне мовлення, критичне мислення, вторинний текст навчальний переклад, комунікативна компетентність. 